\title{
PROVIDING AFFORDABLE HOUSING FOR LOW-INCOME PEOPLE IN INDONESIA (DEVELOPMENT OF MODEL ON HOUSING LAW)
}

\author{
Martin Roestamy \\ Post Graduate Law School of Djuanda University of Bogor, Indonesia, mr.khotami@gmail.com
}

\begin{abstract}
The long term goal of this research is to establish a new legal system that is the law of the buildings by releasing it from dependence on the legal regime of the land by addressing the housing backlog, realizing the concept of welfare state to provide housing for Low-Income People (LIP), and a legal and political framework law housing for the people. Furthermore, the specific targets of this study are: to identify the needs of low-income housing technically, economically and socially appropriate, and to design a development model low-income housing legal system is technically, socially and economically adjusted. Methodology of research was social judicial approach, which is the data sources explored through literature studies, interviews, and questionnaires. The actual data collected from LIP in West Java and Jakarta of Indonesia were selected purposefully; The government as the main responsible in the construction of houses for the people's business; such as business agents, public housing developers, and private agencies, those are stakeholders housing and implementation has a considerable role in the construction of houses for the people. Finally, the research has some findings: (1) The development of the legal system of housing up to this research still requires a paradigm shift, both the housing and settlement, as well as the ownership of homes and buildings. The paradigm change shall include the link between home ownership and buildings according to the government, legislation, and society as a user. It was not easy to introduce new life patterns for Indonesian people who are communal and still requiring an understanding in the form of socialization decent standard of low-income housing in terms of technical, economic and social. (2) In a legal perspective, the signal separation of ownership of houses and buildings already exist in the Housing Act, Building Law, Agrarian Law, and Law on Housing and Settlement Region. For a government that will come very important paradigm shift in the Development of housing for LIP. (3) Model development of the construction of houses for the LIP which has been caused by the government's failure who does not have a blueprint for the construction of housing for the LIP, the Development low-income housing cannot be done solely by the technical approach, it also has to do with legal approach to the application of the principle of horizontal separation which can be a way out in the house construction of low-income people. (4) The provision of housing for the LIP should be considered the feasibility of residential house technically, economically and socially.
\end{abstract}

Keywords: Low-Income People, Legal System, Housing, Land Law.

\section{BACKGROUND}

The issue of land acquisition, provision of land, or the land acquisition still requires an extensive roadmap 
throughout the system of land law in Indonesia. Land, in particular, community paradigm is something sacred, conscientious, sensitive, privilege and involving many factions. In practical land acquisition (whether it is provision, transition, compensation or land consolidation) in the perspective of Land Law still keeps many problems in practice, with all the processes and interests. In addition, it is also known that the stakeholder soil is something unlimited, in other circumstances; the availability of land is something limited.

In any event of land acquisition process (also known as land attainment) either by the way of release, transfer or compensation and land consolidation will involve many factions which is called with stakeholders with interests, even stakeholders without interests, such as NGOs, lands' agencies, hooligans, brokers, or in local term known as Biyong (West Java) or Tukang Pakang (Malay), Calo, and other terms in accordance with the area. They are who classified as "stakeholders without interests", just as the cause of the land acquisition program becomes deadlocked and failed to the projects were being neglected, backward or at least delay for a long time. For example, toll road projects. Almost all of the land acquisition for toll road projects, of process, preparation, dissemination, verification, and the transition; often plagued with issues of which was created, although many other issues such as the problem of documentation, price, dissemination and implementation of which requires patience and toughness to negotiate.

In addition to the above issues in theory the principle of balance, justice, rule of law, freedom of contract, is the part that needs attention the implementation of land acquisition, both the transition and the release, which is part of the Civil Code (Hukum Privat), where the parties are rights holders or serf by the parties "liberated lands" have the same position (Equality before the law) protected by the constitution and laws of the country.

Procurement of land for housing and settlement development cannot be separated from classical problems as mentioned above. Lots of land acquisition for the construction of housing, the dispute has been raised from preparation to execution. There are also many crime scenes are up to the field of the court although the certification of land rights has been issued by BPN to on behalf of developers, even the end-user (buyer). This happens to private developers and National Housing Program (PERUMNAS), whose work to provide low-income housing, including subsidized apartment, not in spite of the dispute.

The above phenomenon of which it is a fact that advanced and even became the main issue both for public and law officers. The question is, how is the root cause of the dispute over land acquisition? Seems to have become difficult to disentangle the tangled threads, because it involves parties and sequences. From various studies conducted by the researcher with the University Djuanda and the Notary Office and the Land Official Committee (PPAT), the problem of land acquisition can be identified from several factors as follows:

1. The development of democratization in Indonesia, such as respect for human rights, local wisdom, the principle of Equality Before the Law, as if triggered euphoria, the paradigm of "important fight", not to mention the provocateurs land classified as speculators, NGOs, lands' agencies, hooligans, brokers; sometimes make the land acquisition process became chaotic, and deadlocks. The article of 2 of 2012 on Land Acquisition, especially regarding land acquisition for public purposes, more specifically the acquisition of lands for the housing for Low-Income People.

2. The land has become a commodity of trade and investment, as a consequence of land prices soar, and keep the land from the people, so that there is a saying: "The land is getting higher in the sky." In particular, the procurement of land for housing and settlement for the LIP, a direct impact on house prices, for urban areas may be said of the lower class, or are poor, almost say cannot afford housing footprint, while the construction of flats is not irrespective of the problems of land acquisition, although the new paradigm suggests that home ownership separate from the land as stipulated in the enactment Law of housing (see Articles no. 46, 47, 48 and 49)

3. The existence of negative style principle of land registration that makes land registration has no legal certainty, even if the right holder has the strongest legal position, but the principle of respect for the rights of the old is also a problem.

From some problems and problems of land acquisition as mentioned above, the many people who missed the presence of the institutions that can provide a way out for the acquisition of lands for the construction of infrastructure, housing and settlements, including investment.

\section{LAND AND HOUSING}

\subsection{Horizontal Perspective Separation}

Mariam Darus Badrulzaman (1982) gives an example of the use of horizontal separation principle in Basic Agrarian Law Act (UUPA) as follow: "UUPA does not embrace an attachment principle but horizontal 
separation had been taken from the Customary Law. The sale and purchase of rights over a land does not automatically include buildings and plants on it. If building and plants are to be included, it has to be clearly stated in the deed of sale and purchase."

Ter Haar (1981), a student of Van Vollenhoven, stated that rights over a house and over planted plants are basically separated from rights over land on where those goods exist. Therefore, horizontal separation principle can be perceived as a doctrine that separates the ownership of land from the ownership of goods attached to it. This includes a land transaction or land sale and purchase. As a matter of fact, there are also some problems in the application of horizontal separation principle in customary law. In customary law, the application of this principle is restricted by certain things.

Iman Sudiyat (1978) inventories these restrictions as follows:

1. Transaction of yard usually includes house and plants. This makes the house and plants, in addition to the yard, as the object of the sale and purchase. Besides, people may also trade the house and plants separated from the land.

2. Sometimes, rights over plants (and over the house) come together with rights over a piece of land related to the plants and house.

3. Rights over land are not separated from rights over a concrete house which is not movable without any damage (different from bamboo or wooden house). With these restrictions, the following uncertainties might occur.

4. Whether a house should be considered as a concrete house or not.

5. How big is the size of land that should be considered as a house yard; yet all of these do not nullify the point.

6. In a relation between rights over a house and plants and rights over land in a royal atmosphere, there is an unusual custom that rights over land is called the King's right and the land is called a King's land (in Javanese: Keagungan Dalem). Yet, individual rights over land, in fact, is recognized as such, and they do it by saying it as rights over house and plants. The authority of the government to take actions and burden the restrictions of rights is done in such a way as if it is based on the King's rights over land, yet virtually is done based on the King's power to govern.

It can be seen from the above explanation that as development keep occurring in the society, the horizontal separation principle is not strictly applied as shown by the recognition that a concrete house is considered different from a bamboo or wooden house that can be removed away. However, this does not nullify the principle that land and other goods on it are separated. The application of horizontal separation principle at present time, especially in Indonesia, is regulated in and refers to UUPA which is still enacted. However, in practice, this is not totally applied as articles about vertical attachment principle in Indonesian Civil Code are still embraced even though juridical they should be repealed as they are already differently regulated in UUPA. However, if UUPA should be the one to be referred to, the application of horizontal separation principle should be applied consistently. This is really important as there is an urgent need to fulfill.(Roestamy, 2015)

\subsection{Housing}

A house has to be built to fulfill people need to be seen from numerous basic factors related to human needs. One of the most basic human needs is physiological need, including shelter. (Martin \& Loomis, 2012) The shelter should be the one that gives safety and comfort and bring social benefits for the family as well as the neighborhood. Giving safety and comfort means that the house should be able to be used to protect its dwellers from various kinds of dangers including the collapse of the house itself. Therefore, the house should be built as a strong and durable structure as a strong and durable house gives its dwellers a safe and comfortable feeling. Therefore, there are some criteria of a decent house.

Technically, a shelter or a house has to meet a standard quality as a decent house. In general, Low-Income People (LIP) want to have a house building which is technically decent or meet the following criteria. It has to be a simple house with the simple bathroom, an open but roofed room, and a bathroom facility. The type of the house should be $21 / 60,36 / 72$ type, or erected on $100 \mathrm{M}^{2}$ of land. The building should have a strong construction to protect the dweller from the danger of building collapse. The house building should be constructed by using red bricks. In short, a strong house means that the house should be built with a strong construction so that it can protect the dwellers from the danger of building collapse and provide comfort to the dwellers during their stay in the house. 
The house has to be durable and strong. Durability means that the house should be long lasting. For durability, the materials used should meet the quality standards and the construction work is done following the appropriate procedures. Besides, building maintenance and control have to be done on a regular basis especially on parts that need replacement or rejuvenation. There are different orientations between respondents in Bogor City and Bogor Regency and those in Depok City and North Jakarta City. In Bogor City and Bogor Regency, respondents tended to choose durable and strong buildings although they were expensive. Respondents in Depok City and North Jakarta City, on the contrary, preferred buildings which were durable, strong, and affordable. This difference might be caused by different prices of buildings in those areas. This difference in prices was caused by the difference in land value. For example, in an advertisement, an office building and $450 \mathrm{M}^{2}$ of land in Penjaringan Jakarta Utara (Pantai Indah Kapuk) was sold for Rp144,000,000,000 or Rp320,000,000 per $\mathrm{M}^{2}$. In Kelapa Gading, North Jakarta, however, a building of $25,000 \mathrm{M}^{2}$ was sold for Rp16,250,000,000 which was equal to Rp650,000 per $\mathrm{M}^{2}$ only. Another $540 \mathrm{M}^{2}$ of land in Kelapa Gading was sold for Rp7,500,000,000 or Rp13,888,889 per $\mathrm{M}^{2}$. These different prices were subject to the differences in building quality and location. Based on the information from Urbanindo (www.urbanindo.com/) as per 14 May 2014, the price for all properties was Rp24,395,458 per $\mathrm{M}^{2}$, for a house only Rp28,250,413 per $\mathrm{M}^{2}$, and for land only Rp17,193,170 per $\mathrm{M}^{2}$. Compared to North Jakarta City, Depok City had cheaper prices of land and house. In Depok City, a house-sized $75 \mathrm{M}^{2}$ with a land sized 160 $\mathrm{M}^{2}$ was sold for Rp475,000,000 which was equal to Rp2,968,750 per $\mathrm{M}^{2}$. Another house sized $1126 \mathrm{M}^{2}$ with a land sized $2860 \mathrm{M}^{2}$ was advertised for sale for Rp10 billion or equal to Rp3,546,099 per $\mathrm{M}^{2}$. On average, based on the information from Urbanindo (www.urbanindo.com) as per 14 May 2014, the price for all properties was $\mathrm{Rp5}, 212,213$ per $\mathrm{M}^{2}$, for a house only $\mathrm{Rp5}, 410,326$ per $\mathrm{M}^{2}$, and for land only $\mathrm{Rp} 1,884,395$ per $\mathrm{M}^{2}$. In Bogor Regency, a house-sized $48 \mathrm{M}^{2}$ with a land sized $84 \mathrm{M}^{2}$ was advertised for sale for Rp385,000,000 or equal to Rp5,000,000 per $\mathrm{M}^{2}$. Based on the information from Urbanindo (www.urbanindo.com) as per 14 May 2014, the price for all properties was Rp4,157,217 per $\mathrm{M}^{2}$, for house only Rp5,013,481 per m2, and for land only Rp1,265,301 per $\mathrm{M}^{2}$. In Bogor City, a house-sized $21 \mathrm{M}^{2}$ with a land sized $50 \mathrm{M}^{2}$ was advertised for sale for Rp140,000,000 or equal to Rp3,000,000 per $\mathrm{M}^{2}$. Based on the information from Urbanindo (www.urbanindo.com) as per 14 May 2014, the price for all properties was Rp4,157,217 per $\mathrm{M}^{2}$, for house only Rp5,013,481 per $\mathrm{M}^{2}$, and for land only $\mathrm{Rp} 1,265,301$ per $\mathrm{M}^{2}$. This showed that there was no significant difference in prices of land and house in Bogor City and Bogor Regency.

Another criterion is that a house should look beautiful and comfortable to reside. Beauty is an element that can add more values to a house so that the dwellers feel proud and have higher self-esteem by living in it. This is usually taken care of by people who can afford a house whose condition is higher than a minimum standard for a shelter. To make a beautiful house, the proportion between structure and room organization has to be carefully considered. Sanitation and cleanliness must be the most important element. Health element is important to consider as health is also a human basic need. Therefore, a building plan has to consider the cleanliness and health of its environment. Attention has to be given to the following factors: sewerage (sanitation), rubbish disposal, lighting, aeration, and room temperature and humidity.

For LIP, the expected housing should have at least 3 closed rooms for a bedroom, a restroom, and a multifunction room that can function as a living room, a family room, or even a dining room and kitchen. As for the Minimum Space Standards, it can be calculated based on space requirement for a person to do basic activities inside the house. These activities include sleep, eat, work, sit, take a bath, defecate and urinate, wash, cook, etc. Studies found that a minimum space requirement is $9 \mathrm{M}^{2}$ per person for a house with the average ceiling height of $2.80 \mathrm{M}^{2}$.

Simply healthy housing allows its dwellers to live a healthy life and do daily activities in a decent way. Minimum room requirement for simple, healthy housing is determined by taking into account the following factors: space requirement per person, space requirement per Head of Household $(\mathrm{HH})$, building space per $\mathrm{HH}$, land requirement per building unit, health and comfort need, house lighting requirement, and sunlight access as a day natural lighting. Standards of decent housing according to the UN Universal Declaration of Human Rights in UNESCAP (2008) are:

1. Basic service and infrastructure: A dwelling has to have facilities to provide health, safety, comfort, and supporting facilities for clean water, an energy source for cooking, heating, lighting, sanitation, garbage disposal, storing, and emergency condition.

2. Affordability: A decent dwelling should be affordable so that every household can have it without reducing its ability to cater for the need.

3. Livable: A dwelling has to be able to protect its dwellers from cold, heat, rain, or other health threats and to provide enough space for the dwellers. 
4. Accessibility: Everyone including marginalized people has the right to have a decent house. Access should be given to marginalized people to a dwelling place and this access should prioritize their rights for land allocation and land use plan.

5. Location: Housing should be located in a place with access to working place, health service, educational service, child care center, and other social facilities. This requirement applies in both urban and rural areas. It should also be far from polluted area or source of pollution.

6. Cultural reflection: A housing area should be built in such a way that reflect the culture embraced by the dwellers but at the same time it should also adopt the use of modern facilities.

Compared to the requirements set by UN, the kind of housing expected by LIP mentioned above is very modest. This modest expectation might reflect the problems faced by them. Poverty is the main problem faced by LIP that makes most LIP live in indecent housing. So complicated is their poverty problem that they do not even dare to dream of having a decent house. (Roestamy, 2015)

\section{BACKLOG AND HOUSING}

Housing is considered as a basic right for Indonesia's citizen as stated in UUD 1945: "every person has the right to pursue happiness, to dwell and obtain a good and healthy environment and the right to health services". In line with Indonesia's Law, as agreed by the international community and stated in the Global Strategy for Shelter in the Year 2000, it is the responsibility of all governments to provide adequate and affordable shelter for all. This commitment was further strengthened by the Habitat II Conference in Istanbul, which declared that the right to housing is part of human rights. In Indonesia and most developing countries, providing adequate and affordable housing for millions of the urban poor is one of the most difficult challenges. It is predicted that in 2004, the housing backlog reached 5.8 million units and increased to 7.4 million units in 2009 (Kemenpera, 2009). Every year more than one million housing units should be built to meet Indonesia's housing demand.(Iriansyah, 2011; Setioko \& Pandelaki, 2015)

The great majority of households occupy a non-attached dwelling unit and the total stock is approximately 54 million housing units of which approximately 24 million are in urban areas. Although the overall quality of the housing stock appears to be fairly good (using the household's own assessments the BPS Housing and Settlement Survey of 2004 indicate that 95 percent of the housing stock is in good to moderate condition), there are still over 2.5 million units that require urgent replacement. The State Ministry of Housing estimates a backlog of 6 million and a requirement for new housing of more than 1 million per year if the backlog has to be removed by 2020. This is the official policy goal and an enormous challenge for the government. There is a great awareness that reaching this goal will require a major expansion of the micro and mortgage housing finance systems.(Hoek-smit, 2006) Moreover, the backlog on 2014 recently it reaches 15 million.(Roestamy, 2015)

From that facts, it's found that The great majority of households occupy a non-attached dwelling unit and the total stock is approximately 54 million housing units of which approximately 24 million are in urban areas. Although the overall quality of the housing stock appears to be fairly good (using the household's own assessments the BPS Housing and Settlement Survey of 2004 indicate that 95 percent of the housing stock is in good to moderate condition), there are still over 2.5 million units that require urgent replacement.

\section{LAND BANK AND LAND TENURE}

According to Law No. 5 of 1960 (known as UUPA) of article 2, paragraph (1) item "a" is mentioned: States regulate and organize allocation, use, inventory, and maintenance of earth, water, and space. Part of the right to control the country, has authorized the state, especially the President of the Republic of Indonesia through the BPN, giving delegated to local governments regarding land matters, then more specifically on land acquisition as stipulated in Law No. 2 of 2012 on Land Procurement which in article 4 paragraph (1) states that the government and/or local governments guarantee the availability of land for public purposes. And in chapter 6 jo. Article 11 stated that: Procurement of land for public interest held by the central government or local governments. Or state-owned institutions may also request the procurement of land for public purposes. What is meant by the Public Interest is the interest of the nation, the state and society should be realized by the government and used for the greatest prosperity of the people which include:

1. Defense and national security;

2. Public roads, highways, tunnels, railways, railway stations, and railway operation facilities;

3. Reservoir, dam, irrigation, drinking water supply, drainage and sanitation, and other buildings;

4. Ports, airports, and terminals; 
5. Infrastructure oil, gas, and geothermal;

6. Generation, transmission, substations, network, and power distribution;

7. The Government of telecommunications and information networks;

8. Place waste disposal and treatment;

9. Hospital/regional government;

10. The public safety facilities;

11. The public cemetery/regional government;

12. Social facilities, public facilities, and public green open space;

13. nature reserve and cultural heritage;

14. Office of Government/Local Government/village;

15. Structuring urban slums and/or consolidation of land, and housing for low-income people with the status of the lease;

16. Infrastructure or school education/regional government;

17. Infrastructure Sports/regional government; and

18. Common Market and a common parking lot. (As stipulated in Article 10 of the Law No. 2 of 2012)

The process of land acquisition shall include the following phases: planning, preparation, execution and delivery of results (execution). In the process, as stipulated in article 9, paragraph (2) The provision of land for public purposes conducted under the principles of balance (also considered the public interest) as well as the provision of adequate compensation and fair. Understanding decent and fair intended to do with the mechanism of transfer of rights or a waiver. As for the interests of residential areas and settlements for LIP carried by also taking into account the provisions set forth in Article 105, 106, and 107 of Law No. 2 of 2012 regarding the provision of land set include: Procedures for the provision of land by way of granting rights, land consolidation, transfer of rights, waiver of land by the owner, the use of state property, wastelands. Especially with regard to the transfer of rights or compensation or consolidation of land is done with regard to the rights holders of the land on either already registered or unregistered (unregistered) including land directly controlled by the state or indigenous lands. Land acquisition is not registered to receive recognition from this law, in the United States in land acquisition are also recognized against unregistered land.

In the case of land that is directly controlled by the state or unregistered land, land rights granted after the offender housing and settlement development as the applicant's rights to land finalize compensation for the whole community cultivated by consensus. if there is no agreement on compensation, the settlement is conducted in accordance with the provisions of the legislation. In this case, the process of transfer of rights or compensation referred to, pays attention to the principles of private law, including the principle of legal certainty to the meaning of the terms of the agreement as set out in Article 1320 of the Civil Code and such article, remains a benchmark.

By law, in accordance with the authority land acquisition process always involves the role of the Notary/PPAT in particular in the implementation of the compensation, transfer and discharge rights. As an official public may be authorized by law to make the deed as set in the Civil Code, in the role of the Notary should be fair or impartial, it is guaranteed by the Act. In the process of restitution of land and the position of the notary must be in the center position and is free of pressure from the community, government, owners, stakeholders, NGOs or from protests either.

In practical, although the notary is responsible only for the formal correctness, in the practice of land acquisition either transition or compensation, is also performed by Sociological Approaches to the law, such as customary law see the structure or the rights of inheritance and tradition and customs, behaviors, and local wisdom, this is done to avoid the overlapping, duplication and safeguard the rights for the weak side, which can only be in a position that is not free. In line with the dignity of the notary thorough, impartial and independent; in accordance with the provisions of the law.

Not infrequently the issue of inheritance to be one of the crucial problems during the process of land acquisition, sometimes the heirs did not recognize other heirs or inheritance disputes. Perhaps due to the heirs see the magnitude of the nominal or because of the influence of third parties on the land acquisition process to be freed. Or it could be because of the legal culture of society regarding awareness of land 
registration, given the significant costs and require considerable time.

Here, a Notary/PPAT should be viewed not just law in its civil alone, but also respect for the customary law and sociology of law including the Anthropology of law such as the habit of shifting cultivation, in the case of land acquisition for plantations, which should see the history of the land by requesting information from officials either from the local village or sub-district officials. In this case, the notary precision is important.

Alternatively, it could also be done through a waiver of land acquisition committee, although it is quite possible to land acquisition committee will be under pressure from the local community, or other parties interested or even unauthorized. That is why no wonder that there are parties such as the head or local officials, especially the village chief who selected people who do not get a salary from the government as well as civil servants in general who come to enliven the process of transition or a waiver and indemnity in question. For example, in the case of Land Acquisition for Toll Road Bogor, Ciawi and Sukabumi (BOCIMI) cannot be separated from the conflict of interests, so that its implementation dragged on for nine years cannot be realized. From research conducted by the Center for Study of Property University Djuanda Bogor, it was found that the land acquisition project is loaded with the interests of sharing parties, including land speculators; farmers tie the titling absence including officers in the village or sub-district as described above.

Not infrequently a dispute even after the completion of land registration, they raised concerns or land disputes, due style land registration which adheres style negative, where every person has the right to contest land rights held by others, even if already registered, this means each land that is owned by someone and already own a certificate of proof of the right, can be sued by others who feel they have the right, even though that right is not listed. As a result of style these negatives, there are cases in the city of Bogor, where a descendant of the deceased Asmara, sued for nearly half of the city of Bogor, including the office of Mayor of Bogor, which is claimed as private land belonging to the descendants of the deceased Asmara (Upgrading the Rights on Indigenous Lands, BPN Bogor City, 2009).

Another case is quite popular is the case Meruya Potanigra in West Jakarta, where the original owner sued and won the case, although each of the lots already certificates as proof of land rights. The case has shocked the land registration system in Jakarta. (Tisna Ayu, Oktavianty; Ana, Silviana; Sri, 2013)

The issue of registration of land which has a negative style actually already been done by PP-IPPAT study period 2000-2004 which provides recommendations to the BPN to consider imposing positive style for land ownership rights that have been registered for over 15 years, with regard to the principles verjaring aquisitive for example, but until now negative style is still valid, and this situation must be a concerned issue due to all researchers of Land Law.

It must be remembered that negative style treatment does provide an opportunity to obtain legal certainty which is essential but also jeopardize some of the parties have the right to just arbitrarily (in most cases) can be sued by the other parties are not responsible. If this is maintained forever, then the owner of the certificate uncomfortable because it is not likely one day be surpassed by other evidence, while the process for obtaining the certificate is not an easy affair. In this case, also the accuracy required officers involved in the registration of land, from the village head/village heads, district and local land office.

Furthermore, who is has the right to manage the state granted to certain parties and to manage the soil, also still a legal issue. Legal certainty is also doubtful with a limited time period of 20 or 30 years. if the investment is made by foreigners or people that period disrupts investments, because if the land rights over management rights expire, especially for the industrial zone, the employer or the user rights must reapply and pay the price of land in accordance with the price SVTO times the area of land at a price the same as the original purchase.

Thus the assumption people who have already purchased land at the beginning of the time management right ends it can be considered no longer exists and an abundance of foreign companies closed because of management rights only apply a maximum of 30 years. Therefore, the future of land rights that exist in the BAL should be re-examined, especially in the time period should be extended, a minimum of whether to use rights may be granted up to HGB 50 years old and 75-year concession which is input to the formulation of Law land.

If we look at the problem of land acquisition laws against practices originating from the acquisition of land above it is clear there are many legal issues that make an impression or a direct impact to the legal uncertainty of land acquisition. There is an impression, as the executor of government land procurement for public interest hesitant step for the paths that are final, which gives legal certainty to partner governments or the government itself in the process of land acquisition. No wonder if the government is precisely the demands of land rights holders or heirs and those who feel they have a part of the injured party or parties 
who are not satisfied with the land acquisition. Not only that, even the land that has been completed (done) even certified, but it still does not escape than the dispute. If combined with investments, this situation makes investors count again to continue its investment in Indonesia. The issue of land is one indicator of the weak competitiveness of Indonesia in promoting investment (of course, in addition to labor and taxation issues). But the matter of land acquisition should be seen more comprehensive, simplified so that there is no legal certainty.

Problems of land acquisition by using a Land Bank, once initiated by Supraba Sekarwati Wijayani (2003) in a dissertation that designs recommendation Land Bank in order to build sustainable housing that focuses on the concept of a state of law as the foundation for building Land Bank as well as the development rights of control state with the Model Development Area Pulogadung in industries such as Jakarta or Rungkut in Surabaya, which can be used as early embryonic stages of provision of land.

For residential areas and settlements, especially the LIP, according to the researcher, the delivery model LISIBA and KASIBA conducted by National Company (Perum) Housing in case of Driyorejo Gresik can be used as the initial model, if land acquisition perspective associated with the need for an institution, whether it's Land Bank or other institutions in the process of land acquisition for the purposes of housing and settlement development for the LIP. Initially, the cooperation carried out by the companies under the Ministry of Public Works is a group of "work". Then, in accordance with the provisions in force at the time, the program of LISIBA and KASIBA with KSPP pattern, which has been designated a third party as a housing developer and settlement development, including settlement for LIP. Then in another project, National Housing Program also working with several developers in housing and settlement development to Cengkareng, so Cengkareng thus grew to what it is today. Cengkareng pattern with the development program through the procurement LISIBA KTM. The model was made by Housing either project Gresik or project Cengkareng, can be used as a reference for the beginning or the embryo of Land Bank (Land Banking), it is not possible region by leveraging regional assets or abandoned land in the area, can develop models for land acquisition as done by region or model National Housing Program. No wonder if the government can free National Housing Program of an agent of economic development, with a load must profit to develop an activity as an agent of the housing development without having to charge him profit motive, can only with government policy, specifically to the development of housing and settlement for the LIP, either owned or leased or possibly also the provision of land for construction of residential property that apart from the land, as stipulated in articles 46, 47, 48, and 49 of Law No. 20 of 2012 as mentioned above. Granting ownership of the building as the researcher initiated the dissertation recommend home ownership (property) that is separate from the soil by the application of the principle of horizontal separation, which is then developed with the research of the National Strategy (STRANAS) on the topic: Model Law Development Housing for Providing Homes for LIP and Providing House for the Low-Income People and continued with paradigm Development Model Community for Home Ownership Separated from Land to accelerate the provision of Home to LIP.

If the Model National Housing Program as mentioned above is developed by the authority of the expanded specifically for the procurement of land for the construction of housing and residential areas, especially lowincome, according to the researcher, the application of articles $46,47,48$ and 49 can be paired together to motivate accelerate the supply of homes for LIP, either owned or leased, with a model of the same flats as rusunawa.

The utilization of the land which is the region's assets, empowerment of abandoned land, with land acquisition for the construction of housing and residential areas for LIP both rental and property of the subsidy; The area also can develop sources of soil derived from the company's CSR area, for the provision of houses for the workers or employees. When the land resources can be managed by a body modeled on the Industrial Zone and National Housing Program above, could have formed a regional government as an embryo BLUDs Land Bank in the area. In addition, of course, remain subject to the provisions in force, land acquisition models BLUDs can also use budget funds for basic infrastructure, investment and development of housing and residential areas.(Roestamy, 2015)

Land Bank which is intended, according to the researcher, is a subject of law is a legal entity as it will support the rights and obligations of course as a legal entity, it needs careful thought, about the manner of its formation, the reference to the rules governing the lodging, preferably in the form of the Act, amorphous regulation as a legal entity in accordance with the principles of civil law, given the duties and responsibilities that are complex and not simple. Thoughts on the establishment of land banks are in line with the concept of Land Tenure and can also as a development lease rights, as stated in article 44 and 45 are also missed by investors as freehold or leasehold prevailing in some countries like China or Singapore.

In connection with BLUDs, as mentioned above, local governments regulate local regulation, the basic tasks 
and functional in the activities of the activities of Land Banking. In the United States, Land Banking regulation as a means of land management can be set by each state (Act.), So it could have the government level City, Village or Town, can form the Land Banking.

From the above, it is clear that the establishment of Land Banking is not an impossible, only needed a strong legal foundation with the provisions of Land Banking can only be developed by the regions, does not necessarily have to be managed by the central institution of the center.

\section{CONCLUSION \& RECOMMENDATION}

1. Procurement of land for public purposes has been basically having a rule or a clear legal reference but in the land acquisition process troubleshooting problems that are Sociology of Law, Legal Culture, as well as the implementation of the Good Governance by the responsible authorities still need improvement because many lead disputes as well as the delay in the land acquisition process for the public interest, especially of basic infrastructure, construction of housing and residential areas.

2. Given the paradigm of the ground in the eyes of some people of Indonesia who still regard the land as sacred, sensitive, religious; on the other hand, there are people who have to change the paradigm that makes the land as an investment object even speculation, it is no wonder the procurement of land for any purpose cannot be separated from the conflict, especially not implemented by the competent neither scientific, authority, nor urban people perspective that are affected by traditional law.

3. Thinking about the need for certain institutions, such as the Land Bank as an alternative to land acquisition, or other agencies to develop the institutional authority that already exists, just as National Housing Program, business area Industry, is an alternative that can be developed as a means of land acquisition for the public interest such as infrastructure, constructions housing especially for lowincome people; to achieve legal certainty.

\section{REFERENCE LIST}

Aminudddin Salle, (2007) Hukum Pengadaan Tanah Untuk Kepentingan Umum, Kreasi Total Media (KTM), Jakarta.

Budi Harsono, (2005) Hukum Agraria Indonesia. Djambatan, Jakarta.

Dixon Martin, (2002) Modern Land Law,: Antony Rowe Ltd. England.

Hoek-smit, M. C. (2006). Expanding Housing Finance for Low- Income Housing in Indonesia. Finance, (February).

Iriansyah, N. (2011). A Need for affordable housing in Banda Aceh, Indonesia, 1(2), 189-193.

Martin, D., \& Loomis, K. (2012). A constructivist approach to introducing education. Building Teachers, 72 75. Retrieved from

http://books.google.com/books?hl=en\&lr=\&id=ZVB1zHTzVF8C\&oi=fnd\&pg=PP1\&dq=Building+Teac hers:+A+Constructivist+Approach+to+Introducing+Education\&ots=hHiEIGjYD-\&sig=ml_TGPU8ip3H087k9WvviSNLS8

Hutagalung Arie Sukanti dan Markus Gunawan, (2008) Kewenangan Pemerintah di Bidang Pertanahan, PT Rajagrafindo Persada Jakarta.

Mariam Darus Badrulzaman, (1993) KUHPerdata Buku III Hukum Perikatan Dengan Penjelasannya, Alumni, Bandung.

Martin Roestamy, (2008) Kepastian Hukum Atas Kepemilikan Rumah Dan Bangunan Gedung Oleh Investor Asing Dikaitkan Dengan Asas Nasionalitas Dalam Sistem Hukum Pertanahan Indonesia. Disertasi. Bandung: Program Pascasarjana Program Studi Doktor (S3) Ilmu Hukum, Universitas Padjadjaran Bandung.

(2009) Konsep-konsep Hukum Kepemilikan Tanah dan Bangunan Gedung bagi Asing, Alumni Bandung.

(2015) Providing House for the Low Income People, International Seminar Managemen Social Sience, 
Osaka Japan.

Land Issues on Housing Policy, paper pada International Focus Group Discussion, Universitas Djuanda, 30 Agustus 2016.

Martin Roestamy, Rita Rahmawati dan TN. Syamsah,. (2014) Model Pengembangan Sistem Hukum perumahan Bagi Masyarakat Berpenghasilan Rendah Yang Layak Secara Teknis, Ekonomi Dan Sosial. Laporan Penelitian. Tidak dipublikasikan.

Martin Roestamy, Rita Rahmawati, (2016) Model Pengembangan Paradigma Masyarakat Bagi Kepemilikan Rumah yang Terpisah dari Tanah untuk Mempercepat Penyediaan Rumah bagi Masyarakat Berpenghasilan Rendah, Laporan Penelitian. Tidak dipublikasikan.

Medha Baskara, dari http://www/medha.lecture.ub.ac.id pada tanggal 27 Februari 2012

Muhammad Yamin, dan Abd. Rahim Lubis, (2004) Beberapa Masalah Aktual Hukum Agraria: Pustaka Bangsa Press, Medan.

Panei Geofree Land Tenure in Indonesia, paper pada International Focus Group Discussion, 30 Agustus 2016.

Setioko, B., \& Pandelaki, E. E. (2015). Toward Housing for the Elderly in Indonesia, 5(6).

Sungkana, (2015) Konsep Dasar Land Banking/Bank Tanah, Artikel pada DJKN Kementrian Keuangan.

Supraba Sekarwati, (2003) Gagasan mengenai Pembentukan Bank Tanah (Land Bank) dalam rangka pembangunan perumahan dan permukiman yang berkelanjutan di Indonesia, Disertasi, Universitas Pajajaran Bandung.

Syafruddin Kalo, (2005) Kapita Selekta Hukum Pertanahan, USU press Medan.

Sudiyat, I. (1978). Asas-asas hukum adat: bekal pengantar. Liberty. Retrieved from https://books.google.co.id/books?id=SQocAAAAIAAJ

Ter Haar Bzn, (1981), Asas-Asas dan Susunan Hukum Adat, Pradnya Paramita, Jakarta.

Tisna Ayu, Oktavianty; Ana, Silviana; Sri, S. Dipenogoro L. R. (2013). Diponegoro Law Review Volume 1, Nomor 2, Tahun 2013, 3(7), 1-11. Retrieved from http://ejournal-s1.undip.ac.id/index.php/dlr

The HUD Magazine, (2012) Edisi pertama Berbagi Tanah Untuk Rakyat Dalam Membangun MBR (Masyarakat Berpenghasilan Rendah). Makalah. Tidak dipublikasikan. 